\title{
KESADARAN SEJARAH HUKUM PERANG DAN DAMAI SEBAGAI KHASANAH DUNIA ISLAM
}

\section{ANTON MINARDI}

Dosen Fakultas IImu Sosial dan Ilmu Politik Universitas Pasundan Bandung, Jalan Lengkong Besar No. 68 Bandung, Telp. (022) 4205945 / (022) 4262456, Email: antonminardi@yahoo.com.

\begin{abstract}
ABSTRAK
Sebagai ajaran Islam mencakup berbagai lapangan kehidupan manusia, dan sebagai rahmat Islam memberikan kontribusi positif kepada berbagai komunitas dan telah mewarnai peradaban dunia. Barat yang sekarang maju dan modern tidak terlepas dari kemajuan Islam sebelumnya. Pembangunan bangsa yang beradab masa kini berikut kaidah-kaidah dalam hubungan internasional dipengaruhi oleh ajaranajaran Islam termasuk di dalamnya adalah hokum perang dan damai. Banyak kalangan yang tidak menyadari akan hal tersebut, untuk itu sudah saatnya kita mengakui dan mengemukakan kembali khasanah ilmu pengetahuan Islam sebagai salah satu kekayaan intelektual dunia yang berperadaban modern.
\end{abstract}

Kata kunci: Kesadaran Sejarah Ilmiah, Hukum Perang dan damai, Dunia Islam.

\section{ABSTRACT}

As Islamic teachings cope various fields of human life, and the grace of Islam make a positive contribution to the community and have been coloring various world civilizations. West is now advanced and modern cannot be separated from Islamic world in the previous progress. Development of a civilized nation today following the rules in international relations is influenced by the teachings of Islam including the law of war and peace. Many people are not aware of it, so that it is time for us to acknowledge and restate the repertoire of Islamic science view as an intellectual property in the modern civilized world.

Keyword: History of Scientific Awareness, the laws of war and peace, the Islamic World. 

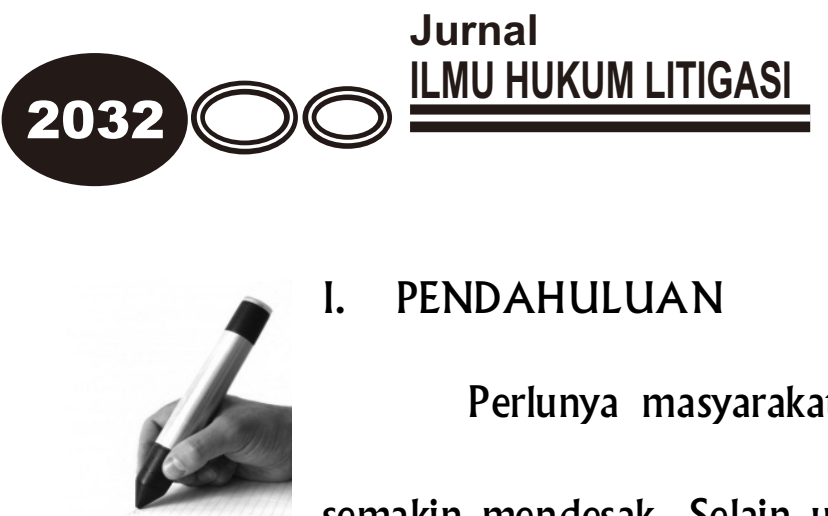

\section{PENDAHULUAN}

Perlunya masyarakat untuk menyadari akar sejarah sudah semakin mendesak. Selain untuk kepentingan mengetahui asal-usul sesuatu akar ajaran dan seting sejarah, tetapi juga untuk mengetahui keajegan suatu disiplin tertentu. Kesadaran akan sejarah juga diperlukan untuk menjadi "penyadar" bagi masyarakat yang sudah "lupa" pada hakikat dan jati dirinya. Masyarakat yang kehilangan jati diri akan menyebabkan mereka terbawa arus kearah yang tidak jelas dan terjebak pada kenyataan yang membuat mereka menjadi kurang beradab.

Kesadaran sejarah menurut Dadan Supardan (Dadan Supardan, 2009: 1), diartikan sebagai suatu refleksi kontinu tentang kompleksitas perubahanperubahan (kontinuitas dan kemungkinan diskontinuitas) yang ditimbulkan oleh interaksi dialektis masyarakat yang ingin melepaskan diri dari genggaman realitas yang ada. Dengan kesadaran sejarah, manusia berusaha menghargai kerumitan upaya pengungkapan bertahap kejadian-kejadian yang melingkupinya, serta menghargai keunikan masing-masing keadaan, bahkan dalam kecenderungankecenderungan yang dikajinya. Oleh karena itu kesadaran sejarah membantu manusia untuk waspada terhadap pemikiran yang terlalu sederhana, analogi yang terlalu dangkal, serta penerimaan-penerimaan pola hukum yang terlalu mudah 
mengarahkan jalannya sejarah ataupun berada dalam cengkraman determinisme sejarah.

Isu keamanan (security) yang lebih luas terjadi seiring dengan cepatnya perkembangan teknologi informasi dan globalisasi. Isu keamanan saat ini tidak hanya berkisar seputar masalah keamanan politik, ekonomi dan militer, tetapi sudah meluas kepada urusan kemanusiaan, pangan, lingkungan hidup bahkan hak intelektual. Mulai dari kasus human trafficking, drug smuggling, global warming, illegal lodging, illegal fishing, hijacking, piracy, sampai intellectual robbery terjadi di mana-mana. Pendekatan untuk menangani terhadap berbagai isu baru itu pun harus dilakukan secara lebih komprehensif. Berbagai konsep menawarkan pendekatan untuk menyelesaikan permasalah tersebut secara komprehensif, di antaranya adalah Islam.

Secara umum ilmu pengetahuan sosial sudah kurang berfungsi untuk dapat memberikan solusi bagi berbagai persoalan kehidupan manusia. Sebagaimana disebutkan oleh Dadan Supardan (Dadan Supardan, Bandung: HISTORIA: Journal of Historical Studies, UPI Vol. X, No.1 (June 2009), 2009: 120 ) bahwa: “apa yang ingin saya angkat dalam judul tentang "kematian ilmu sosial' mengajak kembali pada perdebatan paradigmatik di mana ilmu sosial saat ini nampak kurang berdaya untuk mempertegas posisi dan sikap keilmuannya 


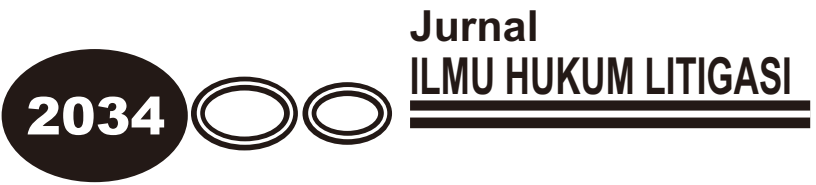

terhadap pilihan-pilihan 'keberpihakan'. Begitu pula dengan Islam yang sesungguhnya merupakan ajaran konseptual sekaligus praktis. Konseptual karena Islam adalah ajaran rasional dan praktis karena Islam adalah ajaran yang harus dipraktekkan dan berisi solusi dari berbagai persoalan manusia dan lingkungannya. Sayangnya saat ini Islam sudah banyak ditinggalkan, sehingga seolah-olah Islam hanya tinggal ajaran konseptual dan terpisah dari kehidupan sosial, politik, ekonomi, budaya dan teknologi.

Islam menawarkan alternatif dari semua permasalahan yang terjadi saat ini. Paling tidak Islam menawarkan solusi baru terhadap berbagai konflik yang ada. Semenjak dahulu Islam dikenal sangat humanis dan anti peperangan. Prinsipprinsip perang dan damai mulai dikenal pada zaman beradab berasal dari peradaban Islam. Permasalahannya yaitu pertama, banyak dari khasanah Islam yang tidak diakui oleh masyarakat internasional dan kaum musliminnya sendiri banyak yang tidak mengetahuinya termasuk mengenai hukum perang dan damai, dimana kalangan barat sendiri mengakui bahwa hukum tersebut banyak berakar dari Islam. Kedua, tantangan utama bagi hukum Islam adalah masih dianggap primitif dan kental dengan sadisme. Apakah benar hukum Islam terutama yang menyangkut dengan hukum perang dan damai primitif dan penuh dengan sadisme? Pada artikel ini penulis tidak akan membahas semua permasalahan di 
atas dan berbagai solusinya, tetapi hanya akan membahas sekelumit mengenai akar sejarah hukum perang dan damai. Tujuan artikel ini adalah untuk menjelaskan bahwa Islam anti terhadap kekerasan dan jauh dari upaya dan praktek terorisme seperti yang sekarang seakan-akan diidentikkan kepada Islam.

Berikut adalah awal perjalanan Islam. Setelah menanamkan aqidah (keyakinan) umat di Mekah selama 13 tahun, Rasulullah (Muhammad SAW.) mendapatkan perintah untuk melakukan hijrah ke Madinah. Setibanya di Madinah Rasulullah melakukan langkah-langkah strategis berikut yaitu pertama, membangun masjid yang kemudian dikenal sebagai masjid Nabawi. Kedua, mempersaudarakan antara kaum muslimin tanpa mengenal latar belakang keluarga, suku, ras dan golongan. Ketiga, membuat traktat yang dikenal dengan Madinah Charter (Piagam Madinah), yang berisi persatuan umat Islam dan non muslim, perjanjian perdamaian, dan perjanjian kerjasama. Diantara butir-butir terpenting dari prinsip-prinsip Piagam tersebut adalah al-musawah (persamaan kedudukan sebagai warga), al-hurriyyah (kebebasan berlandaskan syariat), aladalah (keadilan), al-ukhuwwah (persaudaraan) dan at-tasamuh (toleransi). Di sinilah pemerintahan Islam (khilafah) mulai dibangun dengan metode dan struktur pemerintahannya. 


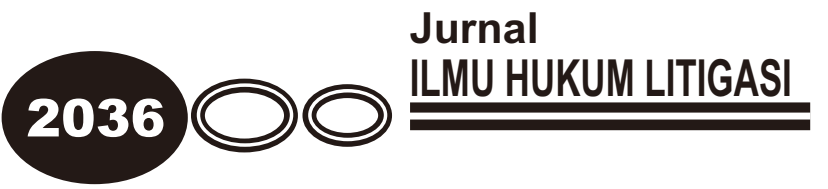

Pada saat khilafah Islam yang pertama yang berpusat di Madinah tersebut, pemerintahan Islam telah memulai hubungan internasionalnya dengan mengirimkan para diplomatnya untuk menyampaikan dakwah Islam kepada para penguasa di belahan yang lain di dunia. Beberapa diantaranya kepada Najasy di Habasyah (Ethiopia), Hiroklius penguasa Romawi (Roma), Kisra penguasa Persia (Iran), Muqauqis di Yaman, dan lain-lain (Hamodurahman, 1976:90-92 dan Altaf Gauhar, 1983:225-228 dan 241, Daud Ali dkk., 1989:92). Delegasi yang diterima Rasulullah SAW pada tahun ke 9 Hijriah (April 630-Maret 631) adalah dari Thaif, Kristen Najran, Bani Sa'ad, Bani Thayyi, Bani Tamim, Bani Hanifa, Raja-raja Himyar dan dari Kinda. (Afzal lqbal, 2000:49-74).

Dakwah terus berkembang dan mencapai ke negeri-negeri yang sangat jauh. Selain mendapatkan kemenangan dalam menghantarkan manusia ke dalam Islam, tetapi juga Islam semakin tersebar ke seluruh dunia. Persia, Mesir, Yerussalem, Romawi, dan sebagainya, jatuh ke pangkuan Islam. Dalam kondisi itulah interaksi antar manusia, kelompok dan lingkungan internasional tidak dapat dihindari, dan tuntutan kepada aturan yang jelas bagi aktivitas mereka di dunia menjadi suatu keharusan. Beragam bentuk kesepakatan, perjanjian dan aturan selanjutnya mewujud menjadi hukum internasional. Yaitu, merupakan suatu tata 
hukum dengan ketentuan-ketentuan yang mengatur pergaulan antara manusia, dan dalam rangka itu menciptakan tertib dan kesejahteraan dalam kehidupannya.

Hukum internasional yang diajarkan Islam bersifat universal karena datangnya langsung dari pencipta manusia yang menguasai berbagai jenis ras dan bahasanya. Sementara hukum yang bersumber dari hasil kajian dan penelitian terhadap perilaku manusia dapat diduga bersifat terbatas. Hukum tersebut berwawasan lokal atau nasional karena dasarnya hanya berasal dari adat istiadat dan perkembangan kehidupan manusia di sekitarnya. Islam menawarkan pendekatan yang universal untuk memberikan kontribusi solutif terhadap berbagai persoalan yang timbul dalam kehidupan.

Adapun dalam tulisan ini permasalahan yang akan dikaji sebagai berikut : Bagaimana kontribusi Islam bagi Hukum Internasional, Bagaimana Perang Damai dalam Hukum Islam, Bagaimana aturan dalam berperang, Apakah Prinsip-prinsip Hukum Internasional Islam dan Bagaimana Realisasinya. 


\section{Jurnal \\ 2038 \\ ILMU HUKUM LITIGASI}

\section{PEMBAHASAN}

A. Kontribusi Islam bagi Hukum Internasional

Ajaran Islam tidak hanya mengurusi Rukun Iman yang "enam perkara" dan Rukun Islam yang "lima perkara", tetapi Islam mengurusi segenap aspek kehidupan manusia terutama yang telah dipraktekkan pada zaman Muhammad SAW. sebagai uswah terbaik bagi umatnya termasuk hubungan internasional atau diplomasi yang berlandaskan pada Al-Qur'an dan As-sunnah.

Sebagai kepala pemerintahan di Madinah Muhammad SAW. menurut Hamidullah (Hamidullah Muhammad, 1968 : 207-208) Muhammad beliau telah biasa menerima duta-duta asing di serambi Masjid Agung Nabawie dimana sampai sekarang masih terdapat pilar para duta sebagai tanda peringatan. Namun di kota Madinah sewaktu nabi masih hidup telah terdapat beberapa tempat yang diperuntukkan khusus untuk menerima tamu-tamu asing itu, antara lain seperti di rumah Ramlah binti Harits Abu Sad.

Lebih lanjut menurut L. Amin Widodo (L. Amin Widodo, 1994 : 47-48) apabila seorang duta atau delegasi asing (daarul kuffar) diterima, maka ada seseorang pemimpin upacara yang akan memberitahukan kepada 
para duta atau delegasi itu formalitas-formalitas secara resmi setempat sebelum mereka diterima menghadap Muhammad SAW. Adapun bagi para kepala negara Islam (Darul Islam) mereka tidaklah dipandang sebagai kepala negara asing sebab itu terhadap mereka diperlakukan sebagai seorang muslim yang mendapat perlakuan sesuai ketentuan hukum Islam.

Saat ini kita mengenal bahwa hukum internasional itu berasal dari pendapat para ahli hukum, jurisprudensi dan perjanjian internasional yang datangnya dari Barat. Barangkali dapat disimak apa yang diungkapkan oleh Hugo Grotius menurut Ali Mansur (Ali Mansur, 1965: 31-42 dalam L. Amin Widodo, 1994:6-7) yang dikenal sebagai “bapak hukum internasional" bahwa hukum internasional pada hakekatnya telah tumbuh sejak lahimya masyarakat manusia didunia ini, akan tetapi sebagai ilmu yang komplit telah dilahirkan dari hukum Islam, sebab agama Islam yang dibawa oleh Nabi Muhammad SAW., yang bersumber pada Al-Qur'an memuat ajaran prinsip-prinsip hukum internasional itu. Hal tersebut dibenarkan oleh Baron Michele de Tubb, seorang guru besar di bidang ilmu hukum internasional pada Akademi Ilmu Negara di Den Haag, yang dalam salah satu pidatonya menegaskan bahwa sesungguhnya bagi hukum internasional itu banyak dilandasi oleh prinsip-prinsip dasar yang terdahulu diletakkan oleh 


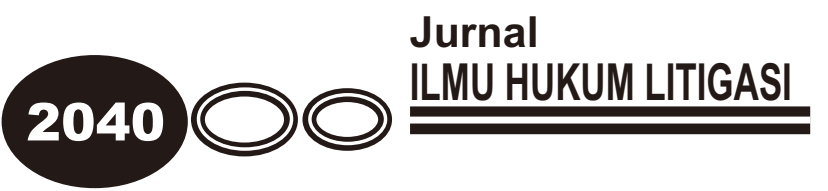

agama Islam, terutama sekali yang bertalian dengan hukum perang dan damai (war and peace). Menurut Mochtar Kusumaatmadja (Mochtar Kusumaatmadja, 1997:21) sumbangan yang terpenting dari dunia Islam menurut dari abad pertengahan terletak di bidang hukum perang.

Misalnya di bidang hukum laut sebelum Grotius menganjurkan adanya ketetapan dalam hukum internasional soal laut bebas dan batas-batas landas kontingen bagi suatu Negara, maka sejak di zaman Daulah Ummayah (9 abad sebelumnya), Khalifah Umar bin Abdul Azis telah menetapkan daerah lautan bebas dan batas-batas landasan kontingen daerah pantai. Hal tersebut terjadi dikala gubernur Afrika Utara memohon kepada khalifah, ijin untuk melarang pedagang-pedagang Eropa Selatan yang memasuki pantai Afrika Utara dengan membawa barang-barang dagangan dan ijin menarik bea cukai bagi para pedagang kaum muslimin di pantai Afrika itu.

Khalifah Umar bin Abdul Azis berlandaskan QS. Al-Baqarah 2:8586, melarang menghalangi pelayaran dilautan bebas dan menarik bea cukai, terkecuali apabila masuk daerah landas kontinen sesuai dengan pakta perjanjian internasional yang telah disepakati antara bangsa-bangsa mengenai daerah "lautan tertutup". Begitu juga Arminazi dalam bukunya Hukum Internasional dalam Islam seperti yang dikutip oleh Mochtar Kusumaatmadja 
(Mochtar Kusumaatmadja, 1997:6-8) menjelaskan bahwa para ahli hukum internasional di Eropa telah mengakui di mana kenyataannya dari bukti-bukti sejarah bahwa hukum Islam menjadi sumber terpenting bagi dasar-dasar hukum internasional yang ada sekarang. Bahkan Gustave Lebon, penulis Perancis ternama mengakui, bahwa renaissance di Eropa yang terjadi 9 abad kemudian setelah lahirnya Islam, maka andil besar yang telah diberikan adalah hukum perang dan damai dari peradaban Islam.

Bukti sejarah menurut Shahib al-Kutb (Shahib al-Kutb, 2004:58) menunjukkan bahwa kaum muslim merintis jalan darat ke India, Cina, Malaysia, dan Timbuktu (pusat perniagaan di Afrika Tengah), serta mengirimkan kafilah dagang ke wilayah yang amat kaya di sepanjang gurun Sahara, jauh sebelum Portugis mencapai Cape Verde. Mereka (muslim) menguasai rute perairan ke India, serta membuat rute di pantai Timur Afrika, dari pantai Sudan dan Socorta hingga ke Mombassa, Mozambik, Zanzibar, dan Madagaskar.

Paling tidak Islam memberikan kontribusi positif bagi hukum internasional yang berlaku saat ini. Pertama, perang hanya boleh dilakukan setelah jalan diplomasi dalam bentuk dialog gagal mencapai kesepakatan. 


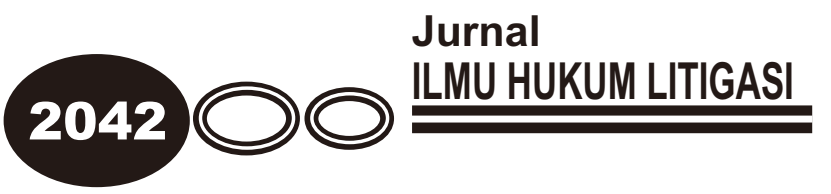

Kedua, apabila perang tidak dapat dihindari, maka wajib untuk melakukan pemberitahuan perang terlebih dahulu kepada pihak lawan. Ketiga, perang tidak boleh menyerang anak-anak, wanita dan orang tua serta dilarang untuk merusak fasilitas umum dan fasilitas kemanusiaan. Saat ini dikenal dengan pembagian kombatan dan non kombatan yaitu pihak yang terlibat perang dan pihak yang tidak terlibat perang. Mereka yang tidak terlibat perang harus terjaga keamanan dan keselamatannya. Apabila terjadi kerusakan pada pihak non kombatan, maka pihak yang merusak wajib membayar ganti rugi kerusakan yang dialami pihak yang dirugikan tersebut. Keempat, perang ditujukan hanya untuk melumpuhkan lawan agar tidak terjadi lagi kesewenang-wenangan, dan bukan untuk memusnahkan dan mencincang lawan. Artinya perang tidak boleh berlebihan dan tidak boleh menggunakan persenjataan yang menyebabkan pemusnahan massal seperti senjata biologis dan senjata nuklir. Kelima, apabila musuh menyatakan menyerah maka harus dilakukan gencatan senjata dan memasang bendera yang berwama putih tanda perdamaian. Keenam, apabila terdapat tawanan perang, mereka tidak boleh dibunuh kecuali yang bertindak sebagai mata-mata. Mereka harus diperlakukan seperti tamu yang harus dijunjung tinggi hak asasi manusianya dan dihormati. Ketujuh, apabila kedua belah pihak telah sepakat untuk 
menghentikan perang, maka selanjutnya dilakukan perjanjian-perjanjian damai antara kedua belah pihak.

B. Perang dan Damai dalam Hukum Islam

Sesungguhnya fenomena kekerasan dan perang dalam berbagai bentuknya terjadi di mana-mana. Tetapi kenapa Islam yang menjadi sasaran dan target operasi perang melawan terorisme? Kita lihat dunia kontemporer bagaimana Uni Soviet (Rusia saat ini) membantai di Chechnya, Serbia membantai Bosnia, India terhadap Kasmir, Myanmar terhadap Rohingya, Israel terhadap Palestina, dan tentu saja Amerika Serikat terhadap Afghanistan, Irak dan sekarang sedang membidik Iran.

Baiklah, Islam menurut L. Amin Widodo (L. Amin Widodo, 1994:6) dikenal memiliki hukum yang lengkap dalam berbagai lapangan kehidupan termasuk hukum internasional dan hubungan internasional. Hugo Grotius seorang ahli hukum internasional bangsa Belanda yang dikenal sebagai "Bapak Hukum Internasional" mengatakan bahwa hukum internasional pada hakekatnya telah tumbuh sejak lahirnya masyarakat manusia di dunia ini, akan tetapi sebagai ilmu yang komplit telah dilahirkan dari hukum Islam, sebab agama Islam yang dibawa oleh Nabi Muhammad 


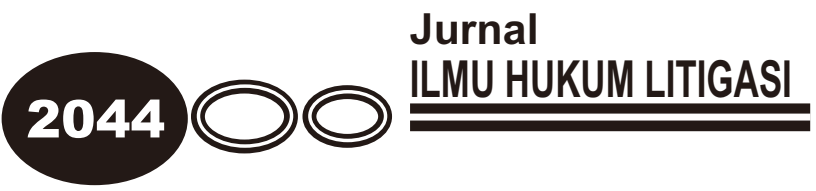

SAW yang bersumber pada Al-Qur'an memuat ajaran prinsip-prinsip hukum internasional itu.

Islam memang membahas mengenai "Perang dan Damai", tetapi daripada membahas perang Islam lebih banyak membahas mengenai Perdamaian. Upaya mendamaikan antara pihak yang bertikai adalah sederajat dengan "Jihad fi Sabilillah". Bahkan kata "maaf" dalam Islam lebih utama daripada "membalas". Al-Qur'an dan Hadis menyebutkan perang dengan istilah al-harb, dan damai dengan as-sulh atau al-ishlah.

Hukum asal perang dalam Islam adalah haram atau dilarang. Berikut ini adalah alasan mengapa umat Islam dibolehkan berperang. Syeikh Yusuf Al-Qardhawi menjelaskan sebagai berikut:

1. Perang terhadap orang-orang yang memerangi kaum muslimin.

Siapapun yang membaca Al-Qur'an dengan seksama, serta menggabungkan antara ayat satu dengan ayat lain, maka akan jelas, bahwa umat Islam disyari'atkan untuk berperang kepada orang-orang yang memerangi muslimin, mengusik kehormatan mereka dan juga kepada orang-orang lemah dari hamba-hamba Allah. Kita lihat beberapa ayat tersebut: 
“Telah diizinkan (berperang) bagi orang-orang yang diperangi, karena sesungguhnya mereka telah dianiaya. Dan sesungguhnya Allah, benarbenar Maha Kuasa menolong mereka itu. (Yaitu) orang-orang yang telah diusir dari kampung halaman mereka tanpa alasan yang benar, kecuali karena mereka berkata, 'Tuhan kami hanyalah Allah' “ (QS. Al-Hajj:39-40).

“Dan perangilah di jalan Allah orang-orang yang memerangi kamu, (tetapi) janganlah kamu melampaui batas, karena sesungguhnya Allah tidak menyukai orang-orang yang melampaui batas"

(QS. Al-Baqarah: 190).

“Tetapi jika mereka membiarkan kamu, dan tidak memerangi kamu serta mengemukakan perdamaian kepadamu maka Allah tidak memberikan jalan bagimu (untuk menawan dan membunuh) mereka" (QS. An-Nisa:90).

“Karena itu jika mereka tidak membiarkan kamu dan (tidak) mau mengemukakan perdamaian kepadamu, serta (tidak) menahan tangan mereka (dari memerangimu), maka tawanlah mereka dan bunuhlah mereka dan merekalah orang-orang yang Kami berikan kepadamu alasan yang nyata (untuk menawan dan membunuh) mereka" (QS. An-Nisa:91). 


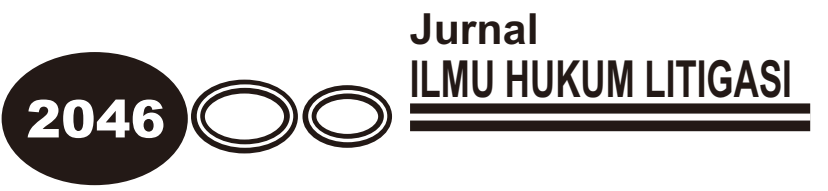

“Mengapakah kamu tidak memerangi orang-orang yang merusak sumpah (janjinya), padahal mereka telah keras kemauannya untuk mengusir Rasul dan merekalah yang pertama kali memulai dan memerangi kamu?"

(QS. At-Taubah:13).

“Mengapa kamu tidak mau berperang di jalan Allah dan (membela) orang-orang yang lemah baik laki-laki, wanita-wanita maupun anak-anak yang semuanya berdo'a, 'Ya Tuhan kami keluarkanlah kami dari negeri ini (Makkah) yang dzalim penduduknya dan berilah kami pelindung dari sisi Engkau dan berilah kami penolong dari sisi Engkau” “ (QS. An-Nisa:75).

2. Perang bukan untuk memaksa orang masuk Islam.

Perang dalam Islam bukan untuk memaksa orang masuk Islam. Islam tidak menyukai tindakan tersebut, paksaan untuk memasuki agama (Islam). Allah SWT. berfirman dalam surat Makiyyah:

“Maka apakah kamu (hendak) memaksa manusia supaya mereka menjadi orang-orang yang beriman semuanya?" (QS. Yunus:99). Dan dalam surat Madaniyah Allah SWT. Berfirman: "Tidak ada paksaan untuk (memasuki) agama (Islam); sesungguhnya telah jelas yang benar daripada jalan yang salah" (QS. Al-Baqarah:256). 
“Dan jikalau Tuhanmu menghendaki, tentulah beriman semua orang yang di muka bumi seluruhnya. Maka apakah kamu (hendak) memaksa manusia supaya menjadi orang-orang beriman semuanya?" (QS. Yunus:99).

3. Perang untuk mencegah terjadinya fitnah dalam agama.

Islam juga mengisyaratkan perang untuk mencegah terjadinya fitnah dalam agama. Allah SWT. Berfirman:

“Dan perangilah mereka, supaya jangan ada fitnah dan supaya agama itu semata-mata bagi Allah" (QS. Al-Anfal:39).

Fitnah adalah perampasan kebebasan manusia dan penindasan terhadap mereka, demi akidahnya. Seperti Ashabul Ukhdud (orang yang dibakar dalam parit besar) oleh para pembesar Najran di Yaman, pembinasaan akal dan kehendak, menghalangi kaum muslimin dari jalan Allah dan beribadah kepada-Nya.

“Mereka bertanya kepadamu tentang berperang pada bulan Haram. Katakanlah, 'Berperang dalam bulan itu adalah dosa besar; tetapi menghalangi (manusia) dari jalan Allah, kafir kepada Allah, 


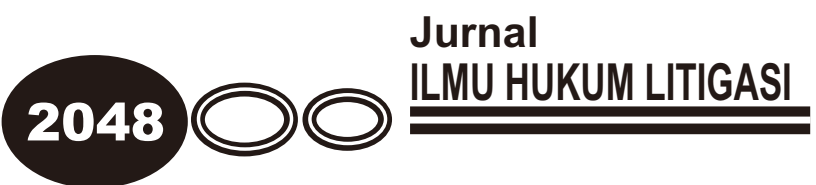

(menghalangi masuk) Masjidil Haram dan mengusir penduduknya dari sekitarnya, lebih besar (dosanya) di sisi Allah. Dan berbuat fitnah lebih besar (dosanya) daripada membunuh" (QS. Al-Abqarah:217).

Intinya, menurut Yusuf Al-Qardhawi (Yusuf Al-Qardhawi, 2003:354-357) Islam mengisyaratkan perang untuk memberikan iklim kebebasan kepada manusia. Beriman dengan kehendak dan atas kesadarannya sendiri tanpa ada sedikit pun paksaan, tidak takut akan fitnah, juga tidak ada pemaksaan dan penindasan dalam beribadah.

Islam sesungguhnya melarang berperang, perang menjadi urusan Allah SWT. dan hanya boleh dilakukan atas izin-Nya. Tiga kondisi yang membolehkan umat Islam berperang yaitu: 1). Ketika diserang dan diperangi. 2). Ketika mendapatkan perlakuan dzolim. 3). Ketika mengalami pengusiran dari kampung halamannya hanya karena mempertahankan keimanan (QS:39-40).

Sementara perdamaian adalah kondisi awal yang seharusnya terjadi seperti pada saat sebelum terjadinya konflik atau peperangan. Allah SWT. Berfirman: "Jika mereka bermaksud berdamai, kemudian engkau pun melakukannya juga..." (QS. Al-Anfal:61). 
Bentuk perdamaian itu hendaknya dibakukan ke dalam suatau perjanjian agar tidak ada alasan dan kesempatan untuk menyalahi kesepakatan perdamaian dan akan ketahuan siapa yang sesungguhnya berkhianat. Allah SWT. berfirman:

“...Tepatilah perjanjian dengan Allah apabila kamu berjanji dan janganlah kamu membatalkan sumpah-sumpah (mu) itu, sesudah meneguhkannya..." (QS. An-Nahl:91).

“Bagaimana bisa ada perjanjian (aman) dari sisi Allah dan rasul-Nya dengan orang-orang musyrik (menyekutukan Tuhan) kecuali orangorang yang mengadakan perjanjian dengan kamu di dekat Masjidil Haram. Selama mereka berlaku lurus terhadapmu, hendaklah kamu berlaku lurus (pula) terhadap mereka. Sesungguhnya Allah menyukai orang-orang yang taqwa" (QS. At-Taubah:7).

Majid Khadduri (Majid Khadduri, 2002:118) seorang ahli hukum internasional menyatakan bahwa seperti halnya jihad, hukum perdamaian secara teoritis hanya alat sementara untuk mengatur hubungan antara kaum muslimin dengan dunia luar selama periode damai (ketika jihad tidak dilakukan), sampai dar al-Islam mencakup seluruh penjuru dunia. Hubungan damai antara dar al-Islam (negara Islam) dan 


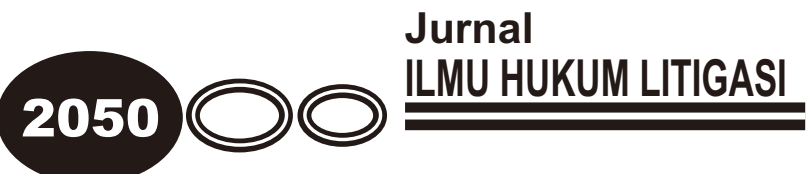

dar al-harb (negara kafir), yang diatur berdasarkan prinsip saling menghormati dan kepentingan tertentu mempengaruhi secara tidak langsung persamaan ide antar dua dar, sebab dar al-harb tidak dapat mendapatkan status normal atau permanen kecuali penduduknya memeluk Islam atau menerima status agama yang ditolerir (Ahli Kitab). Bagaimanapun umat Islam berjuang melalui jihad tanpa terjadi pertumpahan darah, keadaan ini akan mendorong terciptanya suatu perdamaian. Kecenderungan ini sesuai dengan bentuk integrasi modern atas wilayah-wilayah di segenap penjuru dunia yang bersatu dalam satu kesatuan.

Sebuah piagam bernama "Piagam Madinah" merupakan suatu rujukan fakta sejarah pembentukan masyarakat berperadaban modern, sejahtera dan damai. Menurut J. Suyuti Pulungan (J. Suyuti Pulungan, 1996:196-198) prinsip-prinsip umat, persatuan dan persaudaraan, persamaan, kebebasan, hubungan antar pemeluk agama, pertahanan, hidup bertetangga, dan tolong menolong pada hakikatnya menghendaki tercapainya perdamaian di kalangan komunitas Islam dan perdamaian antara komunitas Islam dan komunitas-komunitas lain. Sebab, jika setiap komunitas memelihara dan melaksanakan hak - hak dan kewajiban- 
kewajiban yang terkandung di dalam prinsip-prinsip tersebut, maka perdamaian akan terwujud. Ada lima poin penting yang terkandung dalam (Pasal 17 dan Pasal 45) Piagam Madinah tersebut. Pertama, orang-orang mukmin seluruhnya harus mencapai kata sepakat bila mereka mengadakan perdamaian dengan pihak lain. Kedua, orang-orang mukmin harus memerankan dirinya sebagai golongan yang berinisiatif dalam mewujudkan perdamaian. Ketiga, orang-orang mukmin harus gemar dan bersedia menerima perdamaian yang ditawarkan oleh pihak lain. Keempat, bila perdamaian diprakarsai oleh orang-orang mukmin kemudian diterima oleh pihak musuh, maka perdamaian itu sah dengan persyaratan-persyaratan yang tidak merugikan semua pihak. Kelima, orang-orang mukmin tidak boleh memprakarsai perdamaian dengan pihak yang memerangi agama, atau menerima tawaran perdamaian mereka kecuali mereka menyerah.

Sikap demikian menunjukkan bahwa umat Islam tidak boleh menyimpan dendam apapun terhadap siapapun jika sudah ada Traktat atau Perjanjian antara kaum muslimin dengan mereka, dan hablum min an-nas (hubungan antara manusia) harus kembali baik. Allah SWT. berfirman: 


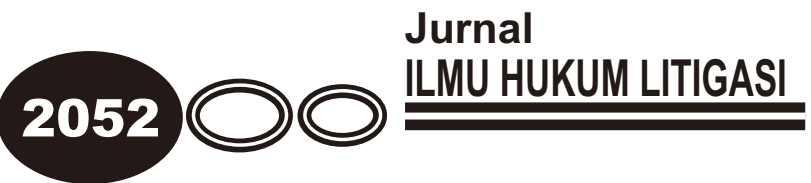

\begin{abstract}
"Allah tidak melarang kalian untuk berbuat baik berlaku adil kepada orang-orang yang tidak memerangi kalian dalam agama dan tidak mengeluarkan kalian dari rumah-rumah kalian. Sesungguhnya Allah suka kepada orang-orang yang berbuat adil".
\end{abstract}

\title{
C. Aturan dalam Berperang
}

Syari'at Islam mengajarkan umat Islam untuk berlaku adil dan baik terhadap manusia tidak saja pada saat damai, tetapi juga pada saat perang berlangsung. Berikut ini adalah akhlak Islam ketika dalam kondisi perang. Imam Muslim meriwayatkan dari Sulaiman bin Buraidah dari ayahnya:

“Apabila Rasulullah SAW. menunjuk seorang pemimpin (amir) sebuah detasemen pasukan atau sebuah ekspedisi, beliau SAW. senantiasa menekankan kepadanya untuk bertakwa kepada Allah dan berbuat baik kepada kaum Muslim yang turut bersamanya. Kemudian beliau SAW. akan memberikan nasihat sebagai berikut, 'Berperanglah atas nama Allah di jalan Allah. Perangilah orang-orang yang ingkar kepada Allah. Perangilah, dan jangan melampaui batas, janganlah berkhianat, jangan mencincang tubuh musuh, dan jangan membunuh anak-anak. Apabila bertemu dengan musuh dari kalangan kaum musyrikin, maka ajaklah mereka pada tiga (pilihan), dan apa pun yang mereka pilih sebagai 
jawaban atas tawaranmu, terimalah, dan berhentilah memerangi mereka. (Pertama) Serulah mereka untuk masuk Islam, dan apabila mereka menerima seruanmu, maka terimalah ia dan berhentilah memerangi mereka. Kemudian serukan kepada mereka untuk berpindah dari wilayah mereka ke wilayah kaum Muhajirin. Sampaikan kabar baik bahwa mereka menerima seruan ini, mereka mendapat hak yang sama dengan hak yang diterima Muhajirin dan mempunyai kewajiban yang sama dengan kewajiban kaum Muhajirin. Jika mereka menolak untuk berpindah (ke wilayah Muhajirin), maka diberlakukan kepadanya bahwa mereka sama seperti orang Badwi Muslim, yaitu tunduk kepada hukum kaum mukmin, namun mereka tidak mendapat bagian fa'i (harta kaum muslimin yang dirampas oleh kafir) dan ghanimah (rampasan perang), kecuali jika mereka mau berperang bersama kaum Muslim. (Kedua) Apabila mereka menolak, perintahkan mereka untuk membayar jizyah; dan apabila mereka menerima seruan ini, terimalah mereka dan berhentilah memerangi mereka. (Ketiga) Jika mereka masih tetap menolak, maka mohonlah pertolongan kepada Allah, dan majulah memerangi mereka". 


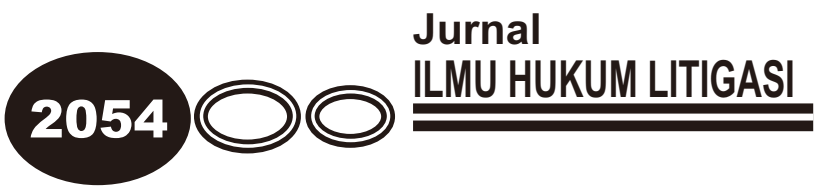

Sikap kehati-hatian ditunjukkan dalam Islam terhadap siapapun bahkan dalam situasi perang. Berikut ajaranya:

Nabi SAW. bersabda kepada para komandan perang: “janganlah kalian berkhianat, melanggar perjanjian, membunuh dengan sadis dan membunuh anak-anak" (Hadits R. Ahmad 1/493).

Nasihat Nabi SAW. kepada Khalid bin Walid pada suatu peperangan: “Janganlah kamu membunuh perempuan dan juga buruh pekerja (budak)" (Hadits R. Abu Daud:2669).

Nabi SAW. bersabda: “Orang paling pemaaf dalam perang adalah orang beriman" (Hadits Abu Daud:2666).

Abu Bakar menasihati komandannya, Yazid bin Abi Sufyan ketika mengirim pasukan ke Syam: "Janganlah kamu membunuh anak-anak, wanita, dan tua renta". Dan dari Umar beliau menasihati Salmah bin Qis: "Janganlah kalian membunuh anak-anak, wanita, dan tua renta" (Al-Mughni 13/178). 
Abu Bakar melarang membunuh para pendeta dalam tempat peribadatan mereka, karena sesungguhnya mereka tidak memerangi orang-orang beragama. Umar berkata: “Bertakwalah kepada Allah pada kaum petani, yang tidak mengumumkan perang kepada kamu" (Al-Baihaqi 9/91 dan Sa'id bin Manshur 2/239).

Ketika dalam peperangan kaum muslimin dituntut untuk sungguhsungguh, tetapi ketika selesai mereka dituntut untuk tidak aniaya dengan memperlakukan tawanan perang dengan baik. Allah SWT. berfirman:

“Apabila kamu bertemu dengan orang-orang kafir (di medan perang) maka pancunglah leher mereka. Sehingga apabila kamu telah mengalahkan mereka maka tawanlah mereka dan sesudah itu kamu boleh membebaskan mereka atau menerima tebusan sampai perang berhenti" (QS. Muhammad:4).

D. Prinsip-prinsip Hukum Internasional Islam dan Realisasinya

Secara umum, menurut T.M. Hasbi As-Sidieqy (T.M. Hasbi AsShidieqy, $1391 \mathrm{H} / 1971 \mathrm{M}: 118-123$ ) hukum internasional menurut Islam mencakup seluruh aspek baik dalam kondisi perang maupun damai. Pelaksanaannya dapat diimplementasikan dalam tiga wilayah yaitu; pertama, 


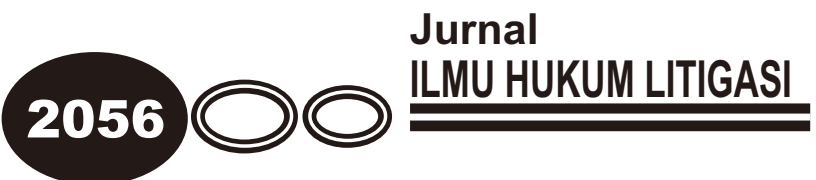

Darul Islam (Negara Islam, yaitu negara hukum yang menerapkan syariat Islam). Kedua, Darul Harbi (negara kafir, yaitu yang negara memerangi hukum Islam). Ketiga, Darul 'Ahdi (negara yang mengadakan perjanjian damai dengan negara Islam).

Adapun prinsip - prinsip dasar hukum internasional dalam Islam adalah :

1. Saling menghormati pakta-pakta dan traktat-traktat (QS. 8:58, 9:487, $16: 91,17: 34)$

2. Kehormatan dan integrasi internasional (QS. 16:92)

3. Keadilan internasional (QS. 5:8)

4. Menjaga perdamaian (QS. 8:61)

5. Menghormati kenetralan negara-negara lain (non combatants) (QS. $4: 89,90)$

6. Larangan terhadap eksploitasi imperialis (QS. 16:92, 28:83)

7. Memberikan perlindungan dan dukungan kepada orang-orang Islam dinegara lain (QS. 8:72)

8. Bersahabat dengan kekuasaan-kekuasaan netral (QS. 60:8,9)

9. Kehormatan dalam hubungan internasional (QS. 55:60) 
10. Persamaan keadilan untuk para penyerang (QS. 2:194, 16:126, 42 : 40-42).

Selain itu menurut Syeikh Syaukat Hussain (Syeikh Syaukat Hussain, 1996:59-95) Islam menegaskan bahwa hak azasi manusia baik yang muslim maupun non muslim, laki-laki maupun perempuan dilindungi undang-undang;

1. Hak hidup (QS. Al-Isra:33, Al-An'am:151)

2. Hak milik (QS. Al-Baqarah:1 88, An-Nisa:29)

3. Perlindungan kehormatan (QS. Al-Hujurat:1 1-12)

4. Keamanan dan kesucian kehidupan pribadi (QS. An-Nur:27, AlHujurat:12)

5. Keamanan kemerdekaan pribadi (QS. Al-Hujurat:6)

6. Perlindungan dari hukuman penjara yang sewenang-wenang (QS. AlAn'am:164)

7. Hak untuk memprotes kezaliman (tirani) (QS. An-Nisa:148, AlMaidah:78-79, Ali Imran: 110)

8. Kebebasan ekspresi (QS. At-Taubah:71)

9. Kebebasan hati nurani (QS. Al-Baqarah:256)

10. Status warga negara non muslim dalam hukum Islam dilindungi (hadits riwayat Abu Dawud) 


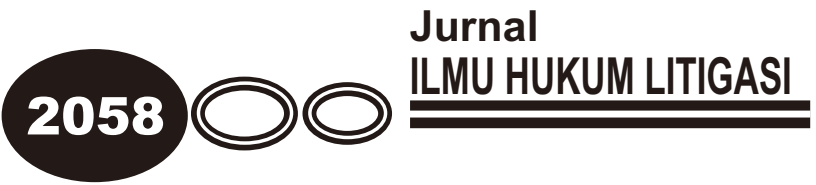

11. Kebebasan berserikat (QS. Ali Imran:104-105)

12. Kebebasan berpindah (QS. Al-Baqarah 84-85)

13. Persamaan hak dalam hukum (QS. An-Nisa:1, Al-Hujurat:13)

14. Hak mendapatkan keadilan (QS. Asy-Syura:15)

15. Hak mendapatkan kebutuhan dasar hidup manusia (QS. AdzDzariyat:19)

16. Hak mendapatkan pendidikan (QS. Yunus:101).

Pelaksanaannya diimplementasikan dalam hubungan internasional Islam yang mendasarkan diri pada beberapa prinsip yaitu: pertama, hubungan internasional dilandasi dengan prinsip untuk memelihara ketertiban dan perdamaian di dunia. Prinsip perdamaian memiliki doktrin sebagai berikut:

1. Umat manusia dan bangsa-bangsa di dunia berasal dari satu orang, yaitu Nabi Adam as.

2. Al-qur'an telah menggariskan suatu ketentuan asasi agar manusia senantiasa menghormati perjanjian termasuk perjanjian perdamaian.

3. Perang hanya diijinkan dalam keadaan-keadaan khusus, yakni apabila keamanan dan pertahanan negara terancam oleh pihak musuh.

4. Islam tidak membenarkan dan melarang paksaan dan kekerasan. 
5. Islam mengajarkan agar perdamaian itu dimulai dari hubungan perorangan.

Kedua, Islam menurut H.M. Daud Ali dkk. (H.M. Daud Ali dkk, 1989:87-92) memerintahkan kepada pemeluknya agar supaya memenuhi persetujuan-persetujuan dan perjanjian internasional. Ketiga, sejak zaman Nabi Muhammad saw, hubungan internasional dilaksanakan dengan cara pertukaran duta atau utusan (envoys).

Praktek hubungan internasional menurut Hizbut Tahrir (Hizbut Tahrir, 2002:111-118) dalam pandangan Islam kini, adalah:

1. Negara-negara yang ada dewasa ini dalam dunia Islam, seluruhnya dianggap berada di dalam satu.

2. Negara-negara lain, baik yang berada di Barat maupun di Timur, seluruhnya dianggap Darul Kuffar dan statusnya menurut syura adalah termasuk Darul Harb.

3. Dengan negeri-negeri tersebut di atas dibolehkan mengadakan perjanjian bertetangga baik, pejanjian perdagangan, ekonomi, perjanjian ilmiah, perjanjian dalam bidang pertanian dan perjanjian lainnya yang dibolehkan menurut syara. 


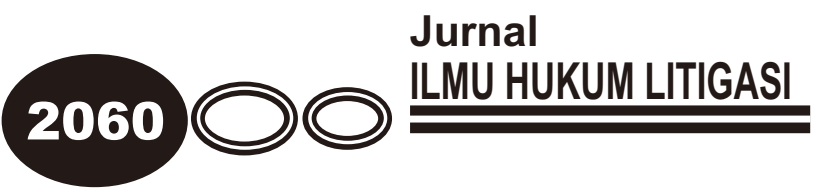

4. Negara-negara lain yang tidak memiliki hubungan perjanjian dengan khilafah dan negara-negara serakah yang ingin menguasai wilayah kaum muslim, seperti Rusia, dianggap sebagai negara-negara musuh (muharibah hukman) ditinjau dari segi hukum. Terhadap mereka diambil langkahlangkah waspada dan siaga penuh, serta tidak akan diadakan hubungan dengan mereka.

5. Negara-negara musuh yang sedang memerangi umat (muharibah fi'lan), seperti Israel, maka terhadap institusi ini diambil sikap siaga perang sebagai asas hubungan dengan mereka (QS. An-Nisa:141, AlBaqarah:194)

6. Negara khilafah tidak diperkenankan mengadakan perjanjian kerjasama militer (pakta pertahanan militer) dengan negara-negara lain, seperti bentuk perjanjian pertahanan bersama atau perjanjian keamanan bersama. Termasuk didalamnya memberikan fasilitas militer, seperti menyewakan pangkalan militer seperti menyewakan pangkalan militer, pangkalan udara atau dermaga kapal perang.

7. Tidak dibolehkan meminta bantuan militer kepada negara-negara kafir atau kepada pasukan kafir (Hadits). Dalam hal larangan ini termasuk 
dalam mengambil pinjaman/hutang dan menyerahkan urusan ke tangan negara-negara kafir.

Khusus bagi negeri-negeri muslim terlebih bagi Indonesia, pelaksanaan hubungan internasional itu hendaknya dengan komitmen melaksanakan "politik bebas aktif" yang bertujuan memperjuangkan kepentingan bersama, membebaskan dari belenggu kapitalis dan komunis serta lembaga-lembaga internasional yang menjerat, membela umat Islam diseluruh dunia dan memajukan Islam. Untuk mewujudkan hal tersebut nampaknya perlu suatu pemerintahan yang peduli akan penerapan syariat Islam, pemerintahan yang sangat mandiri dan berwibawa.

Esensi dari syari'at Islam mengenai kemanusiaan dan perilaku dalam perang dan damai secara lengkap kita dapatkan dalam Islam. Semua ajaran tersebut tidak dikenal dalam ajaran sebelumnya, kecuali Islam. Perilaku awal perang, di dalam perang dan cara mengakhiri perang semua diatur dalam Islam. Termasuk perlakuan yang adil terhadap para tawanan perang dan penduduk dari daerah yang ditaklukkan. Islam mendudukkan manusia secara sederajat dan mengakui hak-hak dan kewajibannya dengan sama. Perbedaannya kemudian adalah pada tugas dan fungsinya sebagai manusia yang memiliki karakter dan keahlian yang berbeda. Hal tersebut juga berlaku 


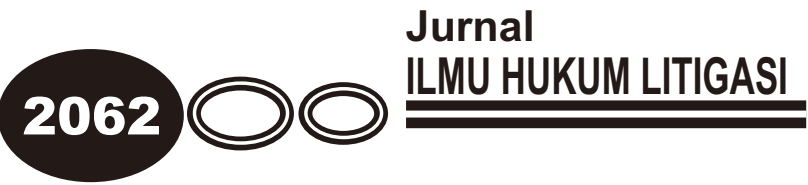

tidak hanya bagi Muslim tetapi juga Islam memberlakukannya bagi umat non Muslim.

Saat ini aturan kemanusiaan dituangkan ke dalam berbagai bentuk aturan dan hukum baik dalam deklarasi maupun perjanjian internasional. Semuanya mengacu pada standar ketinggian martabat kemanusiaan. Dunia internasional baru mengakui secara tegas hak azasi manusia agak secara lengkap dalam Declaration of Human Right sebagai dasar berdirinya Perserikatan Bangsa-Bangsa tahun 1945, itu pun masih dengan membedakan nilai kemanusiaan berbadasarkan kekuatan ekonomi, politik dan militer. Sementara Islam telah mendeklarasikan Hak Asasi Manusia pada abad ke 7 masehi sekaligus mengatur urusan perang dan damai dalam percaturan internasional. Kesederajatan manusia, kebebasan yang beradab, persaudaraan, toleransi dan keadilan diajarkan oleh Islam. Prinsip-prinsip tersebut menjadi dasar bagi pembangunan hubungan antara bangsa dan hubungan internasional di masa selanjutnya pada peradaban Islam.

Sementara keistimewaan yang dipaksanakan bagi lima negara menjadi pemicu terjadinya konflik internasional. Lima Negara (Amerika Serikat, Rusia, Cina, Inggris dan Perancis) diberikan keistimewaan dibanding manusia lainnya dan dengan diberikannya hak veto bagi mereka. Dunia internasional 
masih mempraktekkan ketidakadilan kemanusiaan. Padahal inilah mungkin sumber dari ketidakadilan kontemporer dalam segala bidang. Memelihara hak istimewa bagi sebagian kalangan itu berarti memelihara ketidakadilan bagi dunia internasional. Karena manusia memiliki selera dan kepentingan yang berbeda selama hidupnya. 


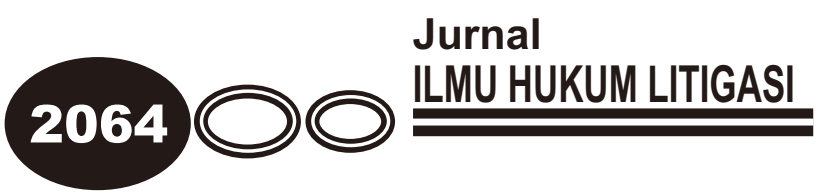

\section{SIMPULAN DAN SARAN}

A. Simpulan

Islam menolak setiap bentuk kekerasan tidak hanya dalam kondisi damai tetapi juga dalam kondisi perang. Kekerasan yang dilakukan dalam perang adalah bersifat sementara dan untuk tujuan melumpuhkan lawan bukan untuk menghancurkan. Ajaran ini memberikan landasan yang kokoh bagi hukum perang dan damai pada dunia modern saat ini.

Paling tidak ada beberapa hal yang dapat disimpulkan dari uraian di atas. Pertama, Islam menanamkan nilai-nilai kemanusiaan yang kokoh dalam kehidupan manusia. Prinsip kesederajatan, kebebasan, persaudaraan, toleransi dan keadilan merupakan dasar kebijakan Islam bagi praktek kehidupan ideologi, politik dan ekonomi kaum muslimin dan hubungannya dengan non Muslim. Kedua, Islam melarang terjadinya perang, dan peperangan merupakan otoritas dari Allah SWT. Dan boleh dilakukan atas izin-Nya. Tiga kondisi yang membuat Allah SWT. mengizinkan umat Islam berperang yaitu: diperangi, didzolimi dan diusir dari kampung halamannya karena mempertahankan keimanan. Ketiga, Islam memberikan adab atau tata cara dalam berperang yaitu tidak boleh merusak, mencincang dan berlebihan. Wanita, anak-anak dan orang tua jompo serta orang yang tidak terlibat dalam 
peperangan (non kombatan) dilarang untuk dibunuh. Tawanan perang mesti diperlakukan seperti kepada tamu, dan tamu dalam Islam sangat diistimewakan. Keempat, Islam menganggap perdamaian merupakan kondisi asal dan kondisi yang memang harus tercipta. Perdamaian adalah sumber pembangunan dan kerja sama, yang menjadi fondasi dari suatu kemajuan. Kelima, Islam menganggap bahwa hubungan internasional adalah fitrah manusia yang didasari oleh saling ketertarikan antar umat manusia yang memiliki keragaman. Esensi hubungan intemasional dalam Islam itu bukan atas dasar ketergantungan atau saling ketergantungan, tetapi atas dasar saling ketertarikan yaitu penerapan konsep dasar "ta'aruf" (saling mengenal).

Ajaran-ajaran tersebut menjadi hal yang tidak terbantahkan untuk dilakukan saat ini. Selain para ahli internasional khususnya ahli hukum internasional mengakui kontribusi yang mendasar dan sangat besar bagi hukum perang dan damai, Islam telah menjadi peletak praktek hubungan internasional kontemporer yang lebih maju. Misalnya pertama, selain kekerasan dalam berbagai bentuk tidak dibenarkan dalam Islam, tetapi juga Islam melarang terjadinya pengekangan kepada kebebasan yang beradab. Kedua, selain itu perbuatan perang yang sangat dihindari Islam dimana praktek pemusnahan sangat dilarang Islam, itu artinya penggunaan berbagai 


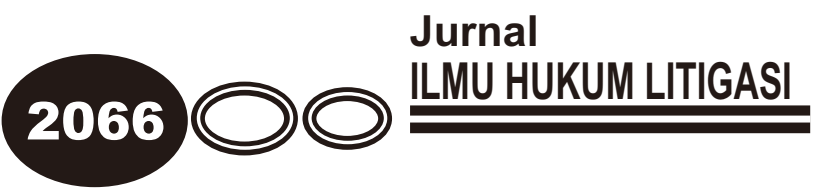

jenis persenjataan yang dapat memusnahkan manusia juga dilarang. Itu juga berarti bahwa Islam melarang penggunaan senjata pemusnah masal seperti senjata kimia atau biologis dan nuklir. Ketiga, perdamaian harus terjaga dengan baik karena hal tersebut merupakan fondasi bagi berjalannya pembangunan kualitas manusia menuju peradaban manusia yang sejahtera. Keempat, hubungan internasional dilakukan dengan dasar saling ketertarikan dan tidak boleh ada bentuk-bentuk ketergantungan. Setiap bentuk ketergantungan sekecil apapun itu akan mengakibatkan bentuk kolonialisme antara yang kuat terhadap yang lemah. Kelima, pelarangan untuk merusak lingkungan dalam kondisi damai maupun perang adalah wujud pemeliharaan Islam terhadap lingkungan di mana manusia itu hidup. Lingkungan dipengaruhi oleh manusia dan sebaliknya kualitas hidup manusia sangat dipangaruhi juga oleh lingkungan. 
B. Saran

Demikianlah Islam memberikan akar yang kokoh dalam hukum perang dan damai. Walaupun banyak penyimpangan yang terjadi dalam hukum internasional khususnya hukum perang dan damai, tetapi warna Islam tersebut tidak dapat dihilangkan begitu saja dalam sejarah kehidupan manusia modern beradab sampai kini. Warna tersebut akan lebih jelas dan cemerlang tentu saja apabila yang sesungguhnya berhak melaksanakannya yang memegang kendali peradaban manusia. Tentu sesuatu yang wajar dan sudah seharusnya umat Islam yang memiliki kekuatan penuh dengan menyatukan segala potensi ilmiah, alamiah dan amaliah yang berpandu pada Ilahiah untuk tampil menjadi para pembaharu dan pemimpin yang mampu menampilkan peradaban baru yang damai, tertib dan lebih sejahtera. 


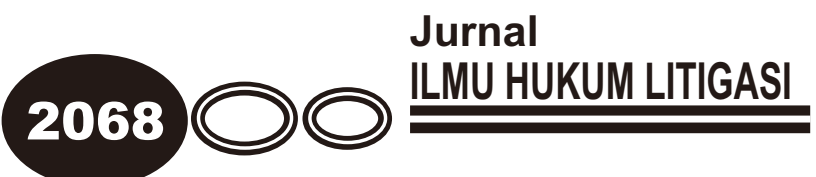

\section{DAFTAR PUSTAKA}

\section{Al-Qur'an.}

Ali, H.M Daud dkk, 1989, Islam untuk Disiplin IImu Hukum, Sosial dan Politik, Jakarta, Bulan Bintang.

Al-Kutb, Shahib, 2004, Science and Islam (Warisan Peradaban Islam di Bidang Sains dan Teknologi), Bogor, Pustaka Thariqul Izzah.

Al-Qardhawi, Yusuf, 2003, Kebangkitan Gerakan Islam, Jakarta, Pustaka Al-Kautsar. As-Shidieqy, T.M Hasbi, 1391 H/1971 M., Hukum Antar Golongan Dalam Fikih Islam, Jakarta, Bulan Bintang.

Hamodurahman, 1976, dan Altaf Gauhar, 1983, dalam H.M Daud Ali dkk., 1989, Islam untuk Disiplin IImu Hukum, Sosial dan Politik, Jakarta, Bulan-Bintang.

Hussain, Syekh Sayukat, 1996, Human Right in Islam (terjemahan), Jakarta, Gema Insani Press.

Iqbal, Afzal, 2000, Diplomacy in Early Islam (terjemahan), Jakarta, Pustaka Kautsar.

Khadduri, Majid, War and Peace in The Law od Islam (terjemahan Kuswanto), Tarawang Press.

Kusumaatmadja, Mochtar, 1997, Pengantar Hukum Internasional, Bandung, Bina Cipta.

Mansur, Ali, 1965, Assyari'atul Islamiyah wal qanunut Daliyu al'am, dalam L. Amin. 
Widodo, 1994, Fiqih Siasah Dalam Hubungan Internasional.:6-7, Yogya, Tiara Wacana.

Muhammad, Hamidullah, 1968, Muslim Conduct of State.

Pulungan, J. Suyuthi, 1996, Prinsip-Prinsip Pemerintahan dalam Piagam Madinah Ditinjau dari Pandangan Al-Qur’an. Jakarta, Raja Grafindo Persada.

Supardan, Dadan, 2009, Anatomi Korupsi dalam Perspektif IImu-IImu Sosial di Indonesia.

HISTORIA, Journal of Historical Studies UPI (Universitas Pendidikan Indonesia), Bandung, Vol. X, No.1, June 2009.

Supardan, Dadan, 2009, Kesadaran Sejarah Sebagai Paradigma Pendidikan, Makalah UPI.

Tahrir, Hizbut, Hizbut Tahrir (terjemahan), 2002.

Widodo, L. Amin, 1994, Fiqih Siasah dalam Hubungan Internasional, Yogya, Tiara Wacana.

HR. Ahmad 1/493.

HR. Abu Daud No. 2669.

HR. Abu Daud No. 2666.

Al-Mughni 13/178. dan diriwayatkan oleh Sa'id dalam Sunan-nya.

Al-Baihaqi 9/91, dan Sa'id bin Manshur dalam Sunan-nya 2/239. 